\title{
How does the Ambience of Cafe Affect the Revisit Intention Among its Patrons? A S on the Cafes in Ipoh, Perak
}

\author{
Sharmeela-Banu Syed AbuThahir ${ }^{1,}$, Gengeswari Krishnapillai ${ }^{1}$ \\ ${ }^{1}$ Department of Marketing, Faculty of Business and Finance, University Tunku Abdul Rahman, Jalan \\ Universiti, Bandar Barat, 31900 Kampar, Perak, Malaysia
}

\begin{abstract}
.
Food service industry is growing rapidly as a result of the changing consumer lifestyle. The food service industry is highly competitive due to the increasing number of new entrants offering inventive food products and services. In order to be outstanding in such competitive industry, retailers nowadays opt to emphasize on their store environment. Past studies discovered that store environment stimulates emotions that significantly boost customer revisit intention. As a result, retailers attempt to differentiate their store by combining various environmental stimuli to create an attractive ambience that will in turn draw in the customers. Hence, this study attempts to investigate the impact of various café ambience factors on the patrons' revisit intention. The patrons of cafes in Ipoh, Perak were selected using purposive sampling technique to be the respondents of this study. 250 questionnaires were collected and Partial Least Square technique was used to analyse the data collected. Findings show that all the five factors of café ambience namely lighting, music, decoration, cleanliness and layouts were significantly influencing the patrons' revisit intention. Of these five factors, lighting was most influential while music was the least influential in affecting the patrons' revisit intention. Accordingly, this study lists several recommendations for practitioners and academics with regards to the store environment and its impact on the repurchase intention.
\end{abstract}

\section{Introduction}

Food service retailers are one of the largest employers' around the world. Food service industry is growing rapidly as a result of the changing consumer lifestyle.Consumer trust in the food industry resulted into the further consumers demandauthenticity, transparency and credibility from all the industry players [57].

\footnotetext{
* Corresponding author: sharmeelas@utar.edu.my
} 
According to Agriculture and Agri-Food Canada [1], food service industries includes cafes and bar, self-service restaurant, full-service restaurants, home delivery and take away, street kiosks, as well as fast food restaurants. Putiy [49] stated that cafe and bar, full service restaurants and fast food restaurants make up the main segment of the food service industry. It consists of more than 8 million food outlets ranging from small family-owned units to large multinational chains operating thousands of stores worldwide.

The global food service industry is projected to reach $\$ 2.2$ trillion in revenues by 2015 as reported in the Business Wire, 2009. Global food market growth is driven by rising disposable earnings, increasing demand for outside food in emerging market and demographic pattern transformation which further boosts the needs for food services. Likewise in Malaysia, majority of Malaysian consumers select to dine out during weekdays or even weekends and public holidays due to their hectic schedules in urban cities and the increased household income [19].

Cafes are typically present in most urban and suburban areas. Due to their creative concepts and relaxing ambience, cafes are usually more exclusive and premium priced than a regular restaurant [10]. Cafes are located at convenient locations around the consumers' place to offer affordable products in a comfortable environment [19]. In addition to that, the increasing disposable income and growing young populations are contributing to the expansions of cafes in Malaysia [68] where these young people characteristically enjoy hanging out with friends at cafes and willing to spend more time and money.

According to Agriculture and Agri-Food Canada [1] the cafe industry in Malaysia is expected to continue to develop and grow as more consumers are choosing to visit these outlets more frequently. Based on the Fig. 1.1, the cafe industry is predicted to achieve a market value of US\$3,707.1 million in coming year 2017 .

Fig.1.1: Forecast Market Value and Growth of Malaysian Foodservice CAGR

\begin{tabular}{|l|r|r|r|r|r|r|}
\hline \multicolumn{7}{|c|}{ Forecast Market Value and Growth of Malaysian Foodservice by Subsector, US\$ millions } \\
\hline & \multicolumn{1}{|c|}{$\mathbf{2 0 1 3}$} & \multicolumn{1}{|c|}{$\mathbf{2 0 1 4}$} & \multicolumn{1}{|c|}{$\mathbf{2 0 1 5}$} & \multicolumn{1}{c|}{$\mathbf{2 0 1 6}$} & \multicolumn{1}{c|}{$\mathbf{2 0 1 7}$} & CAGR \% 2013-17 \\
\hline Consumer Foodservice (Total) & $10,511.2$ & $11,064.4$ & $11,648.7$ & $12,275.5$ & $12,939.1$ & 5.3 \\
\hline Full-Service Restaurants & $3,594.8$ & $3,779.6$ & $3,975.1$ & $4,191.5$ & $4,431.3$ & 5.4 \\
\hline Cafés/Bars & $3,027.4$ & $3,186.8$ & $3,353.4$ & $3,527.5$ & $3,707.1$ & 5.2 \\
\hline Street Stalls/Kiosks & $2,098.2$ & $2,189.9$ & $2,292.2$ & $2,405.9$ & $2,529.5$ & 4.8 \\
\hline Fast Food & $1,513.2$ & $1,614.3$ & $1,718.0$ & $1,823.5$ & $1,929.1$ & 6.3 \\
\hline Self-Service Cafeterias & 204.1 & 211.7 & 219.4 & 229.2 & 237.1 & 3.8 \\
\hline $\mathbf{1 0 0} \%$ Home Delivery/Takeaway & 73.5 & 82.1 & 90.6 & 97.9 & 105.0 & 9.3 \\
\hline
\end{tabular}

$\mathrm{CAGR}=$ compound annual growth rate

Source:Agriculture and Agri-Food Canada, Global Analysis Division. (2014).

Foodservice Profile: Malaysia. Ottawa, ON:Author.

Store atmosphere is defined as the attributes which enhances the ambience of the store with diverse combination of elements such as lighting, music, colour, and scent (Levy \& Weitz, 2009). According to Namasivayam \& Lin [46] store atmosphere is crucial as it affects customer's behaviour as well as their cognitive, emotional, and physiological state. In addition to that, it is proposed that store environment stimulates emotions that significantly boost customer revisit intention [54].

Various past studies [35, 43] adopted the Mehrabian-Russell model to understand the influence of store atmosphere on customer's response. According to the model, 
environmental stimuli which denotes the physical and non-physical element of a store affects the emotional state of the customer in terms of pleasure, arousal or dominance which in turn influences their approach or avoidance response. According to Chen, Peng, and Hung (2015), this model hasbeen applied in various contextssuch as retail, service, leisure, and tourism.

Figure 1.2: The Mehrabian-Russell Model

Figure 1

The Mehrabian-Russell Model

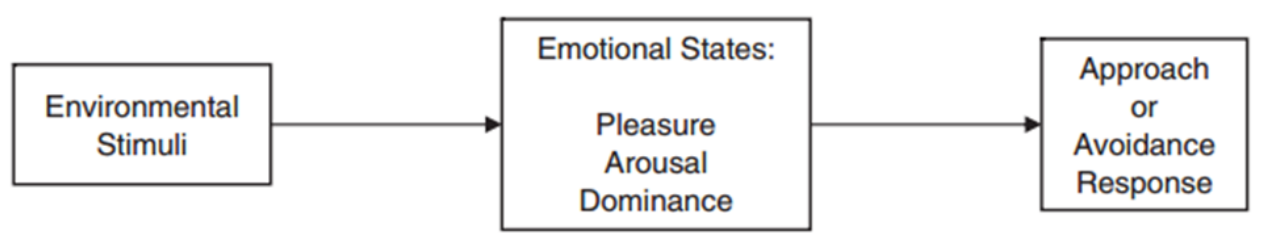

Source:Ryu, K., \& Jang, S. C. (2007).The effect of environmental perceptions on

behavioral intentions through emotions: The case of upscale restaurants.

According to Voon [65] the food service industry is highly competitive due to the increasing number of new entrants offering inventive food products and services. As a result, retailers attempt to differentiate their store by combining various environmental stimuli to create an attractive servicescape that will draw in the customers [69]. It has been found that most of the previous studies only focused on a particular servicescape dimension instead of evaluating several dimension together at once [53, 28,41$]$. As a result, those studies are not suitable to the retailersnowadays who usually combine several atmospheric stimuli to enhance their store appearances. As for this research, it intended to provide accurate result by using several store environment stimuli to evaluate its impact on customer revisit intention.

Hussain and Ali [34] supported by stating that customer nowadays are requesting for additional elements such as store environment instead of food quality. Cafes with pleasant store environment are more likely to attract walk-in customers which trigger their revisit intention. In accordance to that, retailers are willing to spend a substantial amount of resources to improve their store design and other related activities [37]. Despite, most of the retailers are uncertain of which store attributes are deemed important by customers.

Although there are ample studies conducted on the effect of store environment on customer behaviour in the retail world [30] there are limited empirical research evaluating the effect of store environment on customer satisfaction and revisit intention in the food service industry, cafes in particular. In fact, several researchers who studied on the food service industry particularly at foreign countries such as Hong Kong and Sri Lanka. Therefore, this study will concentrate on the customer behaviour towards different store environment attributes which influences their revisit intention. Additionally, the finding may provide an insightful indication to the café owners around Ipoh on consumer behaviour.

\section{Literature Review}

Chen et al. [15] described customer revisit intention as customer's intention to revisit the same restaurant and theytend to recommend it around their circle (i.e. family and friends). The revisit intention is further explained as the repurchase intention and action that shows 
the customer's willingness to provide positive information about the service provider [61]. In the meantime, revisit intention also connected to the customer's decision to build an everlasting relationship with the service provider [33]. According to the past studies, customer satisfaction is the influencing factor for customer's revisit intention [26] hence; customer satisfaction enhances customer loyalty [3] which in turn encourages the customers' revisit intention. Conversely, Chiu, Hsu, Lai, \& Chang [16], emphasized that customer satisfaction leads to customer retention whereas retaining current customers are highly cost-effective than attracting new customers. Also, Jiang \& Rosenbloom, 2005 added that greater customer retention cause positive escalation on the firms' business profitability.

Customer preferences towards music affect their customer satisfaction (Shashikala \& Suresh, 2013). Hence, Han et al. [27] explained that café owners should fine-tune background musicby changing its volume (i.e. loud to soft), tempo (i.e. fast to slow), and genre (i.e. classical or jazz), based on customer's interest to arouse consumers' emotional states. Similarly, Brattico and Jacobsen [12] claimed that music has an impact on emotions, mood, and pleasure. Furthermore, Rea, MacDonald, and Carnes [51] agreed that the mood of the listener can be positively or negatively influenced depending on the type of music played. They added that classical and pop music increases listener's feeling of ease and decreases feeling of worry or tension. Besides, music affects the customer viewpoint of waiting time for service at restaurants and cafes [9, 48]. According to Kim [39], popular music increased the duration customers spend in a café compared to unpopular music which influences dine-in experience.

On the whole, Soriano (2002) insisted that music as one of the elements of ambience which have major effect on the customer revisit intention. Besides, music has been directly stimulates the consumer behaviour to revisit the café (Bonn, Joseph-Mathews, Dai, Hayes, $\&$ Cave, 2007).Therefore, the following hypothesis is proposed:

H1: Music has a significant effect on the revisit intention to the cafes.

According to Morin, Dube, \& Chebat [45], lighting affects customer's behavior in restaurants. Custers, de Kort, IJsselsteijn, \& de Kruiff [17] supported by explaining that lighting influences customer's emotions, mood, and cognition. Dimmed lighting createsan intimate environment for the customer [17] however, Jacquier and Giboreau (2012) indicated that brightness of the lighting is important for customers to read the cafes' menu. Past studies by Houser, Tiller, Bernecker, and Mistrick [32] Vaccaro, Yucetepe, TorresBaumgarten, and Lee [63] Ariffin, Bibon, \& Raja Abdullah, [5] found that adequate lighting influences customer's impression towards the café ambience and enhances customer revisit intention.

Ryu and Jang [56] supported that lighting elements of store have great impact on the customer intention to visit the retailer for repurchase action. Moreover, the customers believe that the pleasant lighting in the café indicates the quality of the service provider [57]. Furthermore, Ramlee \& Said [50] asserted that lighting is one of the important characteristics of intangible dimensions which greatly

affecting non-visual sense of consumer perception towards café selection. Therefore, the following hypothesis is proposed:

$\mathrm{H} 2$ : Lighting has a significant effect on the revisit intention to the cafés.

According to Barber, Goodman, and Goh [8] the cleanliness of a foodservice business includes the dining room and tableswares, the kitchen, as well as the restroom. Hussain \& Ali [4] described cleanliness as the store's appearance that improves the atmosphere and 
enhances customer's reaction towards the store. Cleanliness is the most significant attribute that influences customer's perception of service quality [8] and satisfaction level [58]. According to Kaul (2005), a store with clean physical facilities yields satisfaction and develop revisit intention. Besides that, cleanliness generates positive evaluation among customer and encourages them to stay longer [2,34]. Long et al. (2011) found that people are typically more comfortable in a clean environment, which in turn affects the amount of time they spend in the cafe. Customers will predict the cleanliness of the kitchen based on the dining room surroundings and the appearance of the employees [56] which also influences their evaluation of the food quality [41].

Banat \& Wandebori [6] has argued that the cleanliness of café affects the customer feeling towards the café whether to revisit the café again in the future. Furthermore, Gajanayake, Gajanayake \& Surangi [22] supported that the level of cleanliness able to create an image of comfort and luxury among customers' which affect the customer revisit intention. Therefore, the following hypothesis proposed:

H5: Cleanliness has a significant effect on the revisit intention to the cafes.

VanBaren [64] claimed that the store layout is the design ofa store's interior to provide maximum exposure of merchandise. Well-planned layouts are essential to facilitate in-store traffic patterns [66] and increased customers' efficient movement through the store [62]. Store layout in café should emphasize on the seating arrangement, equipment and furnishing which increases customer satisfaction and leads them to spend longer hours in the café [30]. Hence, those items are able to facilitate café performance in increasing customer revisit intention.

Study of Tlapana(2009) ascertained that the layout and display such as furnishing and the arrangements of the equipment in the café would influence the customer revisit intention. Be sides, Hart, Farrell, Stachow, Reed, \& Cadogan [29] added that the spatial condition of the store influences the consumer attitude towards café selection. Therefore, the following hypothesis is proposed:

H3: Store layout has a significant effect on the revisit intention to the cafes.

Decoration and artifacts are vital components for developing attraction of consumers towards the pleasant appearance of the café setting which influences the consumer overall satisfaction and loyalty $[35,39]$. The decoration of cafe enhances customer satisfaction and thus increases their intention to revisit café [14]. Besides that, decorations and artifacts help customers to develop their first impression of the overall ambience of the café [60]. Long, $\mathrm{Ka}$, Fong, and Lo (2011) added that when the cafe is well decorated with superior quality artifacts, customers are more likely to classify the café as providing high-class and superior service quality. The determination of superior quality artifacts influenced by various aspects of interior designs such as color scheme applied in the café wall or ceiling, paintings, floor coverings, and quality furniture which able to create the overall visual gratification [41].

Decoration and artifacts is the physical environment that induces perceptual and emotional responses among customer that affect the consumer revisit intention (Ali \& Amin, 2014). Meanwhile, Wilson, Zeithaml, Bitner, \& Gremler [67] ; Ryu \& Han [55] stressed that the decorations and artifacts of the café not only create aesthetic impressions, but it also employed as an indicator of differentiation of the chosen dining environment which leads to the customer revisit intention. Therefore, the following hypothesis is proposed: 
H4: Decorations and artifacts have a significant effect on the revisit intention to the cafes.

\section{Research Methodology}

This study was conducted in Ipoh, Perak where regular visitors of 10 chosen cafes were approached to participate. The 10 cafes were chosen due to their popularity and as they were recommended by numerous sources. Purposive sampling technique was used to select the target respondents where there were filtered based on their familiarity and frequency of visit. Hinkin et. al [31] ascertained that an ideal sample size should have an item to response ration of between 1:4 to 1:10. Accordingly, the ideal sample sizeof this study should range from 96 to 240 as there were 24 items in the research instrument. On the other hand, Cattell recommended that a research with three or more independent variables should have a minimum sample size of 250 elements [18]. In view of the typology of Cattell and Hinkin, it was decided to have a sample size of 250 elements in this study. Prior to the actual fieldwork, a pilot study was conducted among 30visitors of three most popular cafes in Ipoh, Perak. Based on the feedbacks received, the word "store" was changed to "café" in order enhancesthe clarity of the items in the instrument. All the 250 sets of responses were retained for further analysis after ticking the requirements of data cleaning process. The data was analysed using Partial Least Square technique.

\section{Discussions}

As shown in Table 1, there were more female (64\%) respondents and majority of the respondents were within the age group 21-25 years old (38.4\%) and visited the café at least thrice in a month (42\%).In order to further apprehend the impact of these demographic characteristics on the research variables investigated, independent sample t-Test (i.e. as for the Gender) and one-way analysis of variances tests (i.e. as for the Age and Frequency of visits) were done.

Table 1: Summary of Demographic Characteristics 


\begin{tabular}{|l|l|l|}
\hline Demographic Characteristics & Frequency & Percentage, \% \\
\hline Gender & 90 & 36 \\
\hline Male & 160 & 64 \\
\hline Female & 69 & 27.6 \\
\hline Age & 96 & 38.4 \\
\hline Below 20 years old & 50 & 20 \\
\hline $21-25$ years old & 35 & 14 \\
\hline $26-30$ years old & 36 & 14.4 \\
\hline Above 30 years & 74 & 29.6 \\
\hline Frequency of visits (in a month) & 105 & 42 \\
\hline 1 & 35 & 14 \\
\hline 2 &
\end{tabular}

Of these 3 demographic characteristics, only "frequency of visit" had contributed a significant difference on all the research variables except the variable of "music" and "light" (refer to Appendix 1). Table 2 summarises the descriptive statistics and an extract of the mean comparison tests conducted. Despite the insignificant overall effect, "frequency of visit" was found to have a significant difference on the "music" between respondents who visit the cafe 3 times and 4 times in a month. Similarly, these two groups of respondents (i.e. who visit the café 3 times and 4 times in a month) were also found to have significant differences on the "layout", "decoration", "cleanliness" and "revisit intention". Respondents who visit the café 4 times in a month were noted to have higher mean values as compared to respondents who visit the café thrice in a month. This implies that the visitors who frequently visit the café tend to place more importance on the various aspect of café ambience alongside their higher revisit intention ascompared to the respondents who visit the café less frequently.

Table 2: One Way Analysis of Variance by Frequency of Visits

\begin{tabular}{|c|c|c|c|c|c|c|c|}
\hline Variables & $\begin{array}{l}\text { Frequency } \\
\text { of visit }\end{array}$ & $\mathbf{N}$ & Mean & STD & F & Sign. & $\begin{array}{l}\text { Post-hoc } \\
\text { (LSD) } \\
\text { Sign. }\end{array}$ \\
\hline \multirow{4}{*}{ Music } & 1 & 36 & 3.7153 & 0.9452 & \multirow{4}{*}{1.979} & \multirow{4}{*}{.118} & 3 vs. 4 \\
\hline & 2 & 74 & 3.6892 & 0.9895 & & & \\
\hline & 3 & 105 & 3.6024 & 1.0230 & & & \\
\hline & 4 & 35 & 4.0571 & 0.6617 & & & \\
\hline \multirow{4}{*}{ Light } & 1 & 36 & 3.6667 & 1.0089 & \multirow{4}{*}{1.173} & \multirow{4}{*}{.321} & \multirow{4}{*}{ NA } \\
\hline & 2 & 74 & 3.5845 & 1.0479 & & & \\
\hline & 3 & 105 & 3.4762 & 1.1242 & & & \\
\hline & 4 & 35 & 3.8500 & 0.9099 & & & \\
\hline
\end{tabular}




\begin{tabular}{|c|c|c|c|c|c|c|c|}
\hline \multirow{4}{*}{ layout } & 1 & 36 & 3.6458 & 1.0271 & \multirow{4}{*}{2.978} & \multirow{4}{*}{.032} & 3 vs. 4 \\
\hline & 2 & 74 & 3.6926 & 1.0183 & & & \\
\hline & 3 & 105 & 3.4214 & 1.1289 & & & \\
\hline & 4 & 35 & 4.0000 & 0.7525 & & & \\
\hline \multirow{4}{*}{ decoration } & 1 & 36 & 3.7083 & 0.9608 & \multirow{4}{*}{3.922} & \multirow{4}{*}{.009} & 2 vs. 4 \\
\hline & 2 & 74 & 3.6757 & 1.0621 & & & 3 vs. 4 \\
\hline & 3 & 105 & 3.4262 & 1.1451 & & & \\
\hline & 4 & 35 & 4.1071 & 0.6510 & & & \\
\hline \multirow{4}{*}{ cleanliness } & 1 & 36 & 3.8264 & 0.8718 & \multirow{4}{*}{3.300} & \multirow{4}{*}{.021} & 1 vs. 4 \\
\hline & 2 & 74 & 3.8784 & 0.9338 & & & 2 vs. 4 \\
\hline & 3 & 105 & 3.7381 & 0.9722 & & & 3 vs. 4 \\
\hline & 4 & 35 & 4.2786 & 0.3364 & & & \\
\hline \multirow{4}{*}{ revisit } & 1 & 36 & 3.7639 & 0.9315 & \multirow{4}{*}{2.571} & \multirow{4}{*}{.045} & 3 vs. 4 \\
\hline & 2 & 74 & 3.7230 & 0.9387 & & & \\
\hline & 3 & 105 & 3.5595 & 1.0252 & & & \\
\hline & 4 & 35 & 4.0571 & 0.5426 & & & \\
\hline
\end{tabular}

The proposed research model of this study was analysed using structural equation modelling (SEM) technique which is a famous second-generation technique. There are two variations in SEM technique namely Covariance-based SEM (CB-SEM) and variancebased SEM (PLS-SEM) where the former is primarily confirmatory in nature while the latter is being [25]. As the current study was not developed to underpin and hence confirm any underlying theory, PLS SEM technique was used to analyse the data collected. The lenient requirements of the measurement model and model complexity were also key reasons to utilise PLS SEM technique in this study.

All the variables of this model are reflective constructs where assessment of construct validity is a must for the reflective constructs [24] Construct validity of this study was assessed based on the model's convergent and discriminant validity. Fornell [20] suggested referringto factor loading (FL) value, average variance extracted (AVE) and composite reliability (CR) inassessingthe convergent validity of the model. Table 3 exhibits the FL, $\mathrm{AVE}$ and $\mathrm{CR}$ of the study's measurement model.

Table 3: Assessment of Convergent Validity

\begin{tabular}{|c|c|c|c|c|}
\hline \multicolumn{2}{|c|}{ Items } & FL & CR & AVE \\
\hline \multicolumn{5}{|c|}{ Revisit Intention } \\
\hline CRl & I would like to consider the café as one of my choices in the future. & 0.8793 & 0.9021 & 0.6975 \\
\hline CR2 & I would like to invite my friends and family along to the café again. & 0.8143 & & \\
\hline CR3 & I would like to experience the pleasant feeling in the café again. & 0.8184 & & \\
\hline CR4 & I would like to build an everlasting relationship with the service provider. & 0.8271 & & \\
\hline \multicolumn{5}{|c|}{ Decoration \& Artifacts } \\
\hline DA1 & $\begin{array}{l}\text { The concept of the decorations and artifacts improves my first impression } \\
\text { on the cafe. }\end{array}$ & 0.9039 & 0.9226 & 0.7488 \\
\hline DA2 & $\begin{array}{l}\text { The uniqueness of the decorations and artifacts encourages me to spend } \\
\text { more time evaluating the cafe. }\end{array}$ & 0.8499 & & \\
\hline DA3 & $\begin{array}{l}\text { The style of the decorations and artifacts encourages me to categorize the } \\
\text { cafe as high-class. }\end{array}$ & 0.8308 & & \\
\hline DA4 & $\begin{array}{l}\text { The design of the decorations and artifacts affects my satisfaction level } \\
\text { towards the cafe. }\end{array}$ & 0.8752 & & \\
\hline \multicolumn{5}{|c|}{ Lighting } \\
\hline $\mathrm{L} 1$ & $\begin{array}{l}\text { The brightness of the lighting allows me to browse through the menu } \\
\text { easily. }\end{array}$ & 0.8915 & 0.9216 & 0.7462 \\
\hline L2 & The dimness of the lighting gave me an intimate / relaxed feeling. & 0.8539 & & \\
\hline
\end{tabular}




\begin{tabular}{|c|c|c|c|c|}
\hline L3 & $\begin{array}{l}\text { The clarity of the lighting allows me to evaluate the overall ambience of } \\
\text { the cafe. }\end{array}$ & 0.827 & & \\
\hline L4 & $\begin{array}{l}\text { The attractiveness of the lighting (e.g.: shape and colour of bulb) enhances } \\
\text { my perception of the cafe's image. }\end{array}$ & 0.8815 & & \\
\hline \multicolumn{5}{|c|}{ Music } \\
\hline M1 & The right genre of music influences my mood in a positive manner. & 0.8731 & 0.9093 & 0.7149 \\
\hline M2 & The tempo of the music increases my willingness to wait for my food. & 0.8326 & & \\
\hline M3 & The rhythm of the music enhances my enjoyment. & 0.844 & & \\
\hline M4 & The appropriate volume of the music helps to reduce my stress level. & 0.8317 & & \\
\hline \multicolumn{5}{|c|}{ Store Layout } \\
\hline SL1 & The accessibility of the store layout enhances my positive evaluation. & 0.8896 & 0.9178 & 0.7364 \\
\hline SL2 & $\begin{array}{l}\text { The design of the store layout encourages me to walk around and select } \\
\text { more food and beverages (e.g.: from the fridge or pastries display) }\end{array}$ & 0.832 & & \\
\hline SL3 & The efficiency of the store layout eases my entry and exit. & 0.8489 & & \\
\hline SL4 & $\begin{array}{l}\text { The creativeness of the store layout (e.g.: seating arrangements) } \\
\text { encourages me to stay longer. }\end{array}$ & 0.8609 & & \\
\hline \multicolumn{5}{|c|}{ Cleanliness } \\
\hline $\mathrm{C} 1$ & $\begin{array}{l}\text { The cleanliness of the café encourages me to have a positive impression } \\
\text { towards the cafe. }\end{array}$ & 0.879 & 0.9019 & 0.6971 \\
\hline $\mathrm{C} 2$ & The cleanliness of the café improves my evaluation of the food quality. & 0.8204 & & \\
\hline $\mathrm{C} 3$ & The cleanliness of the café increases my desire to stay longer. & 0.8009 & & \\
\hline $\mathrm{C} 4$ & The cleanliness of the café enhances my overall satisfaction level. & 0.8376 & & \\
\hline
\end{tabular}

All the items were found to have more than $0.8 \mathrm{FL}$ value (which ranges from 0.8009 to 0.9039)while each construct had achieved a minimum 0.6 of AVE value (which ranges from 0.6971 to 0.7488 ) and good CR score(which rangesfrom 0.9019 to0.9226). Such results evidence that the measurement model hadachieved a fair convergent validity.

On the other hand, discriminant validity was tested by assessing the comparison of items' loading and cross-loading value besides comparing the construct'sAVE and otherconstructs' correlation coefficients (as suggested by Gefen \& Straub, [23]). Table 4 depicts the loading and cross-loading of items where it is notable that each item hadhigher loading value on its respective construct than on other constructs.

Table 4: Item's Loadings and Cross-Loadings

\begin{tabular}{|l|l|l|l|l|l|l|}
\hline Construct/Item & Cleanliness & Decoration & $\begin{array}{l}\text { Store } \\
\text { Layout }\end{array}$ & Light & Music & Revisit \\
\hline CRI1 & 0.7281 & 0.6821 & 0.6744 & 0.676 & 0.583 & $\mathbf{0 . 8 7 9 3}$ \\
\hline CRI2 & 0.6269 & 0.6915 & 0.6512 & 0.6538 & 0.5457 & $\mathbf{0 . 8 1 4 3}$ \\
\hline CRI3 & 0.703 & 0.664 & 0.6479 & 0.6971 & 0.6083 & $\mathbf{0 . 8 1 8 4}$ \\
\hline CRI4 & 0.6426 & 0.6879 & 0.6717 & 0.6838 & 0.5471 & $\mathbf{0 . 8 2 7 1}$ \\
\hline DA1 & 0.6242 & $\mathbf{0 . 9 0 3 9}$ & 0.5757 & 0.6082 & 0.4888 & 0.7341 \\
\hline DA2 & 0.5876 & $\mathbf{0 . 8 4 9 9}$ & 0.5419 & 0.5277 & 0.4626 & 0.6736 \\
\hline DA3 & 0.5535 & $\mathbf{0 . 8 3 0 8}$ & 0.5693 & 0.5416 & 0.4601 & 0.6951 \\
\hline DA4 & 0.592 & $\mathbf{0 . 8 7 5 2}$ & 0.5795 & 0.5777 & 0.4539 & 0.719 \\
\hline L1 & 0.6645 & 0.6024 & 0.583 & $\mathbf{0 . 8 9 1 5}$ & 0.5021 & 0.7503 \\
\hline L2 & 0.5555 & 0.5524 & 0.5193 & $\mathbf{0 . 8 5 3 9}$ & 0.4627 & 0.6679 \\
\hline L3 & 0.5546 & 0.5025 & 0.4439 & $\mathbf{0 . 8 2 7}$ & 0.4859 & 0.6477 \\
\hline L4 & 0.6173 & 0.5861 & 0.5659 & $\mathbf{0 . 8 8 1 5}$ & 0.4651 & 0.732 \\
\hline M1 & 0.5407 & 0.4506 & 0.4855 & 0.5015 & $\mathbf{0 . 8 7 3 1}$ & 0.5986 \\
\hline M2 & 0.4573 & 0.4569 & 0.4744 & 0.4586 & $\mathbf{0 . 8 3 2 6}$ & 0.5608 \\
\hline
\end{tabular}




\begin{tabular}{|l|l|l|l|l|l|l|} 
M3 & 0.4406 & 0.4647 & 0.4614 & 0.4466 & $\mathbf{0 . 8 4 4}$ & 0.5718 \\
\hline M4 & 0.4353 & 0.4512 & 0.4895 & 0.4659 & $\mathbf{0 . 8 3 1 7}$ & 0.582 \\
\hline SL1 & 0.6152 & 0.5967 & $\mathbf{0 . 8 8 9 6}$ & 0.5856 & 0.5164 & 0.7136 \\
\hline SL2 & 0.5187 & 0.5478 & $\mathbf{0 . 8 3 2}$ & 0.4587 & 0.4887 & 0.6275 \\
\hline SL3 & 0.5332 & 0.522 & $\mathbf{0 . 8 4 8 9}$ & 0.4927 & 0.4831 & 0.6618 \\
\hline SL4 & 0.5557 & 0.5791 & $\mathbf{0 . 8 6 0 9}$ & 0.5618 & 0.4531 & 0.7104 \\
\hline C1 & $\mathbf{0 . 8 7 9}$ & 0.6228 & 0.5785 & 0.6763 & 0.5002 & 0.7561 \\
\hline C2 & $\mathbf{0 . 8 2 0 4}$ & 0.5762 & 0.5419 & 0.5549 & 0.4478 & 0.6617 \\
\hline C3 & $\mathbf{0 . 8 0 0 9}$ & 0.5313 & 0.4905 & 0.497 & 0.4524 & 0.6103 \\
\hline C4 & $\mathbf{0 . 8 3 7 6}$ & 0.5396 & 0.5516 & 0.5757 & 0.4507 & 0.6641 \\
\hline
\end{tabular}

In comparing the AVE and correlation coefficients, [21] suggested that theconstruct's AVE square root should be larger than other constructs' correlation coefficients. As shown in Table 5, all the constructsof this studyhad higher square root of AVE than other constructs' coefficients. Based on the two tests conducted, it can be wisely concluded that the modelhad achieved fairdiscriminant validity.

Table 5: Assessment of Discriminant Validity

\begin{tabular}{|l|l|l|l|l|l|l|}
\hline Construct & Cleanliness & Decoration & Store Layout & Light & Music & Revisit \\
\hline Cleanliness & $\mathbf{0 . 8 3 4 9}$ & & & & & \\
\hline Decoration & 0.6814 & $\mathbf{0 . 8 6 5 3}$ & & & & \\
\hline Store Layout & 0.6489 & 0.655 & $\mathbf{0 . 8 5 8 1}$ & & & \\
\hline Light & 0.6944 & 0.651 & 0.614 & $\mathbf{0 . 8 6 3 8}$ & & \\
\hline Music & 0.5549 & 0.539 & 0.565 & 0.5541 & $\mathbf{0 . 8 4 5 5}$ & \\
\hline Revisit & 0.8094 & 0.8158 & 0.792 & 0.8117 & 0.6842 & $\mathbf{0 . 8 3 5 2}$ \\
\hline
\end{tabular}

*BOLD value is the square root of AVE.

Upon confirmingthe reliability and validity of the model, the study's structural model was assessed. It is suggested to assess the possible collinearity issues before assessing the key results of the structural model [25]. Table 6 summarises the collinearity statistics as well as the path's coefficient and T-statistics. All the exogenous constructs were found to have the Tolerance value and Variance inflation factor (VIF) value below than the recommended threshold value of 0.2 and 5 , respectively. On the other hand, it was noted that all the five aspects of café ambience had significant (T-statistics $>1.96)$ and positive influence towards customers' revisit intention to the café. Therefore, all the proposed hypotheses were supported. Of these 5 aspects, "Light" was noted to have highest effect $(\beta=0.2695)$ on the revisit intention and closely followed by the "Decoration" $(\beta=0.2674)$. In addition, "Music" was found to contribute the least effect $(\beta=0.1419)$ on the revisit intention. As a whole, all these 5 aspects of café ambience were found to explain about $88.94 \%$ variances in the customer revisit intention to café. This implies that this study's model has substantial predictive accuracy of $\mathrm{R} 2=0.8894$. 
Table 6: Collinearity Statistics and Path Analysis

\begin{tabular}{|l|l|l|l|l|l|}
\hline \multirow{2}{*}{ Path } & \multicolumn{2}{|l|}{$\begin{array}{l}\text { Collinearity } \\
\text { Statistics }\end{array}$} & \multirow{2}{*}{ Beta } & \multirow{2}{*}{ T-value } & Result \\
\cline { 2 - 6 } & Tolerance & VIF & & & \\
\hline Cleanliness ->Revisit (H1) & .455 & 2.199 & 0.2079 & 3.1364 & Supported \\
\hline Decoration ->Revisit (H2) & .423 & 2.366 & 0.2674 & 4.1444 & Supported \\
\hline Store layout ->Revisit (H3) & .585 & 1.709 & 0.2362 & 3.9283 & Supported \\
\hline Light ->Revisit (H4) & .394 & 2.536 & 0.2695 & 3.9987 & Supported \\
\hline Music->Revisit (H5) & .432 & 2.316 & 0.1419 & 3.1777 & Supported \\
\hline
\end{tabular}

\section{Implications}

This study empirically shows that the five aspects of the cafe music, lighting, cleanliness, store layout, decorations and artifacts have a positive influence on the intention to revisit among the cafe customers. Among all the contributing factors, lighting was the focus of attraction which was noted to have the greatesteffect, followed by the music with has theleast impact towards customer revisit intention to café. In particular, all the five aspects of café ambience explained about 88.94 percent of variances in the customer revisit intention.

Based on the results of the study, lighting is the most important thing that customers are concerned in the selection to revisit their preferred cafe (Table 6). This shows that the lighting elements being the natural pull factor to change customers' perceptions towards their preferred cafe.

The choice of lighting indeed greatly influences the customer revisit intention [56]. Ramlee \& Said [50] affirmed that lighting highly influences the customers in selecting a suitable café for their dine-in activities. In certain conditions, the choice of dim lighting which creates the pleasant and amusing environment demonstrate the quality of the café in providing services [57].

As a guideline, the usage of lighting that is lively with natural elements such as wood, cotton, leather and seagrass to name a few are able to stimulate customer stay in the café. A part from that, the primary concern also centers on outdoor lighting at night using lumens, foot-candles which creates the pleasant and warm environment.

In addition,the decoration and artifactselement of the café werenoted to have second best influence $(\beta=0.2674)$ towards customer revisit intention to the cafe. Past studies found that customer impression towards a café is based on the design elements thatportray uniqueness of the café environment [4]. It was further emphasized that theappropriate choice of decorations and artifacts closely related to the differentiation depictedby the café as high-class service provider [67].

This shows that the café management need to develop an aesthetic café environment to stimulate customer perception and selection of the café. The decorations and artifacts such as classical mix western should emphasizesince it almost certainly able to differentiate an exclusivecafé from thecompetitors. Theattractivefacility aestheticsof the café (i.e. ceiling/wall décor, carpeting/flooring, paintings/pictures, plants/flowers, furniture, and color)are able to develop customer satisfaction and revisit intention.

On the contrary, musicwasfound to contribute the least effect $(\beta=0.1419)$ on the customer revisit intention (Table 6). This may cause of the choice of music selection in the café which leads to endow a modest effect on customer revisit intention. 
Past study of North \& Hargreaves [47] found that customers are giving more considerationto the music that they encountered at home rather than music in public situations in which customers felt they have less control over the music heard. In public, considering the device is important, as customers are using mobile listening devices allow for them to exert control.Supported by Krause, North, and Hewitt [40] discovered that theselection ofinstrument in the café affects the customer's response which influences the customer moodto stay longer in the café.

This suggests that the selection of music such as classical, jazz, and slow tempo music should be blended around the time to create mix-mode environment to the customer. Meanwhile, facilitate customers to choose their own preferred music exerts a strong influence over the ways in which a customer perceives it.

\section{Limitation and Recommendation for Future Researches}

Quantitative research method has been applied to conduct this research. Therefore, it provides modest information on contextual factors to impart deeper understanding which explains the variations in customer's preferences. Moreover, quantitative research focuses on hypothesis testing rather than on hypothesis generation. As a result, the actual store atmosphere affecting customer's revisit intention might be left out from this study.

Future researchers are suggested to pursue either a mixed-method research or qualitative researchmethod in order to evaluatecustomer's opinion or viewpoint, whereby therespondent are able to provide detailed description of their personal experiences for enhanced interpretation.

Another limitation of this study is that it used a cross-sectional study. A crosssectional study only evaluates a situation at one point in time. It does not consider the effect of store atmosphere on customer revisit intention over a period of time. Customers behavioral emotions affecting the revisit intention is not always consistentbased on the factors reviewed since the cross-sectional study less emphasizedthetime factor and its impact tothe variables as a whole. Prospective scholarscanconsider adoptinglongitudinal study to promote a better understanding of customer revisit intention. Longitudinal approach can be used to predict behavioral intention over the time. As such, the model should be validated at different points in time.

\section{Acknowledgement}

The authors would like to extend their appreciationto Chow Pooi Yan, Ho Sim Yee, Ho Tze Yikand Prasna Devi for the help in the data collection process.

\section{References}

1. Agriculture and Agri-Food Canada, Global Analysis Division., Foodservice Profile: Malaysia. Ottawa, ON:Author. (2014)

2. Akinyele, S. T., Customer satisfaction and service quality: customer's repatronage perspectives. Global Journal of Management and BusinessResearch, 10(6), 83-90, (2010)

3. Alegre, J., \& Cladera, M., Analysing the effect of satisfaction and previous visits on tourist intentions to return. European Journal of Marketing, 43, 670-685, (2009) 
4. Ali, F., \& Amin, M., The influence of physical environment on emotions, customer satisfaction and behavioural intentions in Chinese resort hotel industry.Journal for Global Business Advancement,7(3), 249-266, (2014)

5. Ariffin, H. F., Bibon, M. F., \& Raja Abdullah, R. P. S., Restaurant's Atmospheric Elements: What the Customer Wants. Procedia -Social and Behavioral Sciences, 38, 380-387, (2012)

6. Banat, A., \& Wandebori, H. S. T., Store Design and Store Atmosphere Effect on Customer Sales per Visit Economics, Management and Behavioral Sciences, (2012)

7. Barber, N., \& Scarcelli, J. M., Enhancing the assessment of tangible service quality through the creation of a cleanliness measurement scale. Measuring Service Quality, 20(1), 46-69, (2010)

8. Barber, N., Goodman, R. J., \& Goh, B. K., Restaurant consumers repeat patronage: A service quality concern. International Journal of Hospitality Management, 30(2), 329-336, (2011)

9. Berman, B., \& Evans, J. R., Retail Management: A Strategic Approach(10thed.). Upper Saddle River, New Jersey: Prentice Hall, (2007)

10. Bernson,A., The Social Space of The Café: How Service and Physical Design Condition Social Performances(Doctoral dissertation, Wesleyan University), (2011)

11. Bonn, M. A., Joseph-Mathews, S. M., Dai, M., Hayes, S., \& Cave, J., Heritage/cultural attraction atmospherics: Creating the right environment for the heritage/cultural visitor.Journal of Travel Research,45(3), 345-354, (2007)

12. Brattico, E., \& Jacobsen, T., Subjective Appraisal of Music: Neuroimaging Evidence. Ann NY Acad Sci 1169, 308-317, (2009)

13. Campo-Martine, S., Garau-Vadell, J. B., \& Martinez-Ruiz, M. P., Factors influencing repeat visits to a destination: The influence of group composition. Tourism Management, 31, 862-870, (2010)

14. Chang, K., The Effect of Facility Aesthetics and Music onBehaviouralIntention Through Emotion in The Upscale Restaurant Environment. Unpublished master's thesis, The University of Guelph, Guelph, Ontario, Canada, (2012)

15. Chen, A., Peng, N., Hung, K. P., The effects of luxury restaurant environments on diners' emotions and loyalty. International Journal of Contemporary Hospitality Management, 27(2), 236-260, (2015)

16. Chiu, C. M., Hsu, M. H., Lai, H., \& Chang, C. M., Re-examining the influence of trust on online repeat purchase intention: The moderating role of habit and its antecedents.Decision Support Systems,53(4), 835-845, (2012)

17. Custers, P. J. M., de Kort, Y. A. W., IJsselsteijn, W. A., \& de Kruiff, M. E., Lighting in retail environments: Atmosphere perception in the real world. Lighting Res. Technol, 42,331-343, (2010)

18. De Winter, J. C. F., Dodou, D., \& Wieringa, P.A., Exploratory Factor Analysis with Small Sample Sizes. Multivariate Behavioral Research, 44, 147-181, (2009)

19. Euromonitor International., Cafés/Bars in Malaysia. Retrieved July 12, 2015, from http://www.euromonitor.com/cafes-bars-in-malaysia/report, (2015)

20. Fornell, C., A second generation of multivariate analysis. 2. Measurement and evaluation(Vol. 2). Praeger Publishers, (1982)

21. Fornell, C., \& Larcker, D. F., Evaluating structural equation models with unobservable variables and measurement error. Journal of marketing research, 39$50,(1981)$

22. Gajanayake, R., Gajanayake, S., \& Surangi, H. A. K. N. S. , The impact of selected visual merchandising techniques on patronage intentions in 
supermarkets.Paper presented at the Conference on Business and Economic Research, Kedah, MY, (2011)

23. Gefen, D., \& Straub, D., A practical guide to factorial validity using PLS-Graph: Tutorial and annotated example. Communications of the Association for Information systems, 16(1), 5, (2005)

24. Gil-Garcia, J. R., \& Helbig, N., Exploring e-government benefits and success factors. In A.-V. Anttiroiko \& M. Malkia (Eds.), Encyclopedia of digital government. Hershey, PA: Idea Group Inc, (2006)

25. Hair Jr, J. F., Hult, G. T. M., Ringle, C., \& Sarstedt, M., A primer on partial least squares structural equation modeling (PLS-SEM). Sage Publications, (2014)

26. Han, H., \& Ryu, K., The roles of the physical environment, price perception, and customer satisfaction in determining customer loyalty in the restaurant industry. Journal of Hospitality \& Tourism Research, 33(4), 487-510, (2009)

27. Han, H., Back, K. J., \& Barrett, B., Influencing factors on restaurant customers' revisit intention: The roles of emotions and switching barriers. International Journal of Hospitality Management, 28(4), 563-572, (2009)

28. Harris, L. C., \& Goode, M. M., Online servicescapes, trust, and purchase intentions.Journal of Services Marketing,24(3), 230-243, (2010)

29. Hart, C. A., Farrell, A. M., Stachow, G., Reed, G., \& Cadogan, J. W., Shopping Experience Enjoyment: Impact on Customers' Repatronage Intentions, and Gender Influence.Service Industries Journal,27(5), (2007)

30. Heung, V. C. S., \& Gu, T., Influence of restaurant atmospherics on patron satisfaction and behavioral intentions. International Journal of Hospitality Management, 31(4), 1167-1177, (2012)

31. Hinkin, T. R., A review of scale development practices in the study of organizations.Journal of management,21(5), 967-988, (1995)

32. Houser, K. W., Tiller, D. K., Bernecker, C. A., \& Mistrick, R. G, The subjective response to linear fluorescent direct/indirect lighting systems. Lighting Research and Technology, 34, 243-264, (2002)

33. Hume, M., Mort, G. S., \& Winzar, H., Exploring Repurchase Intention in a Performing Arts Context: Who Comes? and Why Do They Come Back? International Journal of Nonprofit and Voluntary Sector Marketing, 12, 135-148, (2007)

34. Hussain, R., \& Ali, M., Effect of Store Atmosphere on Consumer Purchase Intention. International Journal of Marketing Studies, 7(2), 35-43.Jacquier, C., \& Giboreau, A. (2012). Perception and Emotions of Colored Atmospheres at the Restaurant. Proceedings of the 3rd International Conference on Appearance, 165$167,(2015)$

35. Jang, S. S., \& Namkung, Y., Perceived quality, emotions, and behavioral intentions: Application of an extended Mehrabian-Russell model to restaurants.Journal of Business Research,62(4), 451-460, (2009)

36. Jiang, P., \& Rosenbloom, B., Customer intention to return online: price perception, attribute-level performance, and satisfaction unfolding over time.European Journal of Marketing,39(1/2), 150-174, (2005)

37. Kaltcheva, V. D., \& Weitz, B. A., When Should a Retailer Create an Exciting Store Environment? Journal of Marketing, 70, 107-118, (2006)

38. Kim, J. H., The effect of amount of information and music on consumer shopping behaviors in an online apparel retailing setting(Doctoral dissertation, The Ohio State University), (2006) 
39. Kim, W. G., \& Moon, Y. J., Customers' cognitive, emotional, and actionable response to the servicescape: A test of the moderating effect of the restaurant type. International Journal of Hospitality Management, 28, 144-156, (2009)

40. Krause, A. E., North, A. C., \& Hewitt, L. Y., Music-listening in everyday life: Devices and choice.Psychology of music,43(2), 155-170, (2015)

41. Lam, L. W., Chan, K. W., Fong, D., \& Lo, F., Does the look matter? The impact of casino servicescape on gaming customer satisfaction, intention to revisit, and desire to stay.International Journal of Hospitality Management,30(3), 558-567, (2011)

42. Levy, M., \& Weitz, B. A., Retailing Management (7th ed.).Boston, MA: McGrawHill/Irwin, (2008)

43. Lin, I. Y., \& Mattila, A. S., Restaurant servicescape, service encounter, and perceived congruency on customers' emotions and satisfaction.Journal of Hospitality Marketing \& Management,19(8), 819-841, (2010)

44. Liu, Y., \& Jang, S. S., The effects of dining atmospherics: An extended Mehrabian-Russell model.International Journal of Hospitality Management,28(4), 494-503, (2009)

45. Morin, S., Dube, L., \& Chebat, J-C., The role of pleasant music in servicescapes: A test of the dual model of environmental perception. Journal of Retailing, 83(1), 115-130, (2007)

46. Namasivayam, K. \& Lin, I., "The servicescape", in Jones, P., The handbook of Hospitality Operation and IT. New York: Elsevier Publishers, (2008)

47. North, A. C., \& Hargreaves, D. J., Music and consumer behaviour.Oxford handbook of music psychology, 481-490, (2009)

48. Oakes, S., \& North. A. C., The impact of background musical tempo and timbre congruity upon ad content recall and affective response. Applied Cognitive Psychology, 20, 505-520, (2006)

49. Putiy, A., Food Service -Hotel Restaurant Institutional.Moscow, RU: USDA Foreign Agricultural Service, (2011)

50. Ramlee, N., \& Said, I., Review on Atmospheric Effects of Commercial Environment.Procedia-Social and Behavioral Sciences, 153, 426-435, (2014)

51. Rea, C., MacDonald, P., \& Carnes, G., Listening to classical, pop, and metal music: An investigation of mood. Emporia State Research Studies, 46(1), 1-3, (2010)

52. Ribeiro Soriano, D., Customers' expectations factors in restaurants: The situation in Spain.International Journal of Quality \& Reliability Management,19(8/9), 1055 1067, (2002)

53. Rosenbaum, M. S., \& Massiah, C., An expanded servicescape perspective. Journal of Service Management, 22(4), 471-490, (2011)

54. Ryu, K., DINESCAPE, emotions, and behavioral intentions in upscale restaurants. Unpublished doctoral dissertation, Kansas State University, Manhattan, KS, (2005)

55. Ryu, K., \& Han, H. New or repeatcustomers: How does physical environment influence their restaurant experience? International Journal of Hospitality Management, 30, 599-611, (2011)

56. Ryu, K., \& Jang, S., DINESCAPE: A scale for customers' perception ofdining environments. Journal of Foodservice Business Research, 11(1), 2-22, (2008)

57. Ryu, K., Lee, H. R., \& Kim, W. G., The influence of the quality of the physical environment, food, and service on restaurant image, customer perceived value, customer satisfaction, and behavioral intentions. International Journal of Contemporary Hospitality Management, 24(2), 200-223, (2012) 
58. Seung, A. Y., Customer Perceptions of Restaurant Cleanliness: A Cross Cultural Study. Unpublished master's thesis, Virginia Polytechnic Institute and State University, Blacksburg, Virginia, (2012)

59. Shashikala, R., \& Suresh, A. M., A Study on Consumer Perception of Servicescape in Shopping Malls. Vishwakarma Business Review, 3(2), 68-75, (2013)

60. Siu, N. Y., Wan, P. Y. K., \& Dong, P., The impact of the servicescape on the desire to stay in convention and exhibition centers: The case of Macao. International Journal of Hospitality Management, 31, 236-246, (2012)

61. Teng, C-C., \& Kuo, T-H, The combined effects of employee hospitality performance, environment, and entertainment on customer affective response and revisit intention in restaurants. Advances in Hospitality and Tourism Marketing and Management Conference Proceeding, 3-7, (2011)

62. Tlapana, T. P., Store layout and its impact on consumer purchasing behavior at convenience store in Kwa Mashu. Unpublished master's thesis, Durban University of Technology, (2009)

63. Vaccaro, V., Yucetepe, V., Torres-Baumgarten, G., \& Lee, M. S., The Relationship of Music-Retail Consistency and Atmospheric Lighting onConsumer Responses. Review of Business Research, 8(5), 214-221. Retrieved July 26, (2008)

64. VanBaren, J. Store Layout Definition. eHow.Retrieved July27, 2016, from http://www.ehow.com/facts_6951533_store-layout-definition.html, (2012)

65. Voon, B. H.Service Environment of Restaurants: Findings from the youth customers. Journal of ASIAN Behavioral Studies, 1(2), 45-56, (2011)

66. Vrechopoulos, A., O'Keefe, R., Doukidis, G., \& Siomkos, G., Virtual Store Layout: An Experimental Comparison in the Context of Grocery Retail. Journal of Retailing, 80(1), 13-22, (2004)

67. Wilson, A., Zeithaml, V. A., Bitner, M. J., \& Gremler, D. D., Services marketing: Integrating customer focus across the firm. McGraw Hill, (2012)

68. Yee, Y. S., \& Yuen, J. L. F., The Recruitment of Migrant Workers in the Food Service Industry in Malaysia. A Study of Old Town White Coffee and Pappa Rich Kopitiam. International Journal of Business, Economics and Management, 1(10), 291-304, (2014)

69. Zeynep, E., \& Nilgun, G., Congruence between atmospheric cues and store image in fashion retailing. Turkey: Izmir University of Economics, (2011) 